\title{
Healing of Large Segmental Bone Defect after Implantation of Autogenous Cancellous Bone Graft in Comparison to Hydroxyapatite and $0.5 \%$ Collagen Scaffold Combined with Mesenchymal Stem Cells
}

\author{
Alois Nečas ${ }^{1}$, Pavel Proks ${ }^{2}$, Lucie Urbanová ${ }^{1}$, Robert Srnec $^{1}$, Ladislav Stehlík \\ Michal Crha ${ }^{1}$, Petr Raušer ${ }^{1}$, Ladislav Plánka ${ }^{3}$, Jan Janovec ${ }^{1}$, Milan Dvořák ${ }^{1}$, \\ Evžen Amler ${ }^{4,5}$, Lucy Vojtová6 ${ }^{6}$ Josef Jančáŕ ${ }^{6}$ \\ ${ }^{1}$ Department of Surgery and Orthopaedics, Small Animal Clinic, Faculty of Veterinary Medicine, \\ University of Veterinary and Pharmaceutical Sciences, Brno, Czech Republic \\ ${ }^{2}$ Department of Diagnostic Imaging, Small Animal Clinic, Faculty of Veterinary Medicine, \\ University of Veterinary and Pharmaceutical Sciences, Brno, Czech Republic \\ ${ }^{3}$ Department of Pediatric Surgery, Orthopaedics and Traumatology, Faculty Hospital Brno, Czech Republic \\ ${ }^{4}$ Laboratory of Tissue Engineering, Institute of Experimental Medicine, Academy of Sciences \\ of the Czech Republic, v. v. i., Prague, Czech Republic \\ ${ }^{5}$ Institute of Biophysics, $2^{\text {nd }}$ Faculty of Medicine, Charles University in Prague, Prague, Czech Republic \\ ${ }^{6}$ Institute of Materials Chemistry, Brno University of Technology, Czech Republic
}

Received April 6, 2010

Accepted September 21, 2011

\begin{abstract}
At present, attention is focused on research into possibilities of healing large bone defects by the method of mini-invasive osteosynthesis, using implantation of biomaterials and mesenchymal stem cells (MSCs). This study evaluates the healing of segmental femoral defects in miniature pigs based on the radiological determination of the callus: cortex ratio at 16 weeks after ostectomy.

The size of the formed callus was significantly larger $(p<0.05)$ in animals after transplantation of an autogenous cancellous bone graft (group A, callus : cortex ratio of $1.77 \pm 0.33$ ) compared to animals after transplantation of cylindrical scaffold from hydroxyapatite and $0.5 \%$ collagen (group S, callus : cortex ratio of $1.08 \pm 0.13$ ), or in animals after transplantation of this scaffold seeded with MSCs (group S + MSCs, callus: cortex ratio of $1.15 \pm 0.18$ ). No significant difference was found in the size of callus between animals of group S and animals of group S + MSCs. Unlike a scaffold in the shape of the original bone column, a freely placed autogenous cancellous bone graft may allow the newly formed tissue to spread more to the periphery of the ostectomy defect. Implanted cylindrical scaffolds (with and without MSCs) support callus formation directly in the center of original bone column in segmental femoral ostectomy, and can be successfully used in the treatment of large bone defects.
\end{abstract}

Fracture fixation, bone healing, comminuted fracture, callus, ostectomy, buttress plate

In clinical practice the need of surgical solution of extensive bone defects is frequently encountered, either as a result of interrupted integrity of the bone column in comminuted fractures, or in cases of loss of a whole bone segment after ostectomy of tumour-altered bone tissue (Kattapuram et al. 1989). Bone healing is stimulated by local factors and osteoprogenitor cells must be transported into the fracture site (Yoo and Johnstone 1998) which is a complex biological process in cases of serious fractures and ostectomies (Kresten et al. 2006). For the mentioned defect with considerable loss of bone tissue to heal, sufficiently rigid and stable fracture fixation must be chosen (mechanical factors); principles of biological osteosynthesis must be maintained either as minimal atraumatic tissue preparation in the region surrounding the breaking site, or without opening the breaking site e.g. by the method of mini-invasive osteosynthesis using the plate and screws (MIPO = "Minimally Invasive Plate Osteosynthesis") (Krettek and Foreword 1997); and last but not least, other iatrogenic factors must be taken into consideration (duration of 
operation, asepsis). Concurrently, it is advisable to enhance fracture repair not only with regard to osteogenesis and osteoinduction but also osteoconduction and osteopromotion (Attawia et al. 2001). Some strategies of enhancing bone healing (Burwell 1994; Fitch et al. 1997; Bruder and Fox 1999; Marsh and Li 1999; Mason and Renberg 2001; Griffon 2002; Muschler and Midura 2002; Kraus and Kirker-Head 2006) try to take advantage of the natural potential of multipotent mesenchymal stem cells (MSCs) to differentiate into the target tissue cells (Jaiswal et al. 1997; Pittenger et al. 1999). Current possibilities of bone tissue regeneration using experimental transplantations of MSCs combined with biomaterials are summarized in the review of Crha et al. (2009).

The aim of this study was to assess radiologically the healing of segmental femoral defects in miniature pigs based on the mean ratio of callus : cortex. In our knowledge, similar work in a miniature pig has not been published.

Presented results are part of a broader experimental study within the scope of the National Research Programme NPV II 2B06130 that focuses on MSCs transplantations in combination with scaffolds from various biomaterials (Nečas et al. 2008). In the project, we use the locking compression plate (LCP) and locking screws (Synthes ${ }^{\circledR}$ Switzerland) for stabilization of bone fragments in iatrogenic segmental femoral defects in miniature pigs (Nečas et al. 2007; Nečas et al. 2009).

\section{Materials and Methods}

In the miniature pig model $(\mathrm{n}=18)$ iatrogenic segmental bone defect (ostectomy) was created in the centre of diaphysis of the left femur using an oscillating saw in the whole cross-section of the bone at the height of $15 \mathrm{~mm}$. Subsequently the main femoral bone fragments were fixated and stabilized using a five-hole $4.5 \mathrm{~mm}$ titanium LCP (Synthes ${ }^{\circledR}$ Switzerland) and four $4.5 \mathrm{~mm}$ titanium locking screws inserted bicortically, leaving central plate hole empty (unfilled with screw) of the plate at the level of the segmental bone defect. In animals of group A $(n=6)$, this defect was filled with autogenous cancellous bone graft taken from tuberculum majus humeri of the left humerus. In animals of group $\mathrm{S}(\mathrm{n}=6)$, the segmental bone defect was filled with our mechanically self-supporting resorbable nanocomposite scaffold from hydroxyapatite (HAP) and $0.5 \%$ collagen $(1: 1)$ in the shape of a cylinder at the height of $20 \mathrm{~mm}$ and diameter of $15 \mathrm{~mm}$ in the dry state. After moistening, the scaffold becomes elastic and may be compressed and implanted into the bone defect using the "press and fit" method so that it fills out precisely the segmental bone defect and does not get dislocated outside the original bone column. In animals of group $\mathrm{S}+\mathrm{MSCs}(\mathrm{n}=6)$, the iatrogenic femoral defect was filled with the same scaffold from HAP and $0.5 \%$ collagen $(1: 1)$ seeded with mesenchymal stem cells (MSCs).

Radiografic examination of miniature pigs' femurs using imaging methods (X-ray, CT) was done within the scope of individual aims of the whole project NPV II at 2, 4, 8, 12 and 16 weeks from the bone defect creation. After 16 weeks post surgery, the experiment was finished by euthanasia of the experimental animals. Femurs were extracted post mortem and samples were taken from the site of bone defect for further analysis and preparations for histological examination for other studies within the NPV II project. The surgical procedures including appropriate postoperative care and check-up X-ray examinations were performed in complete accordance with the ethical regulations for animal experiments.

For the purpose of this study, bone defect healing was assessed radiologically based on the ratio of the bone callus width in its widest place and the width of the bone diaphysis distally from the bone defect (Grigoryan et al. 2003). Measurements were done on radiographs of the femurs (after removal of the fixation apparatus) in the craniocaudal view $(\mathrm{CrCd})$ taken at 16 weeks after bone defect creation. All measurements were done on digital radiographs (CR Capsula XL/Fuji) in the JiveX program (Visus Technology Transfer GmbH). The resulting values were recorded in one decimal point. The bone callus width (Plate VII, Fig. 1) was measured as the distance of external surfaces of the medial and lateral periostal reaction in the widest place of the callus in the CrCd view (line A). Bone width was measured as the distance of external surfaces of the lateral and medial femoral cortex closely distally from the ostectomy line on the distal bone fragment (line B). The callus : cortex ratio was calculated as portion of the values A and B. For statistical analysis of data Wilcoxon test for unpaired data was used.

\section{Results}

In all pigs $(\mathrm{n}=18)$, the iatrogenic segmental defect of femoral diaphysis was bridged by a bone callus, and in some cases the radiolucent line at the segmental defect site did not exceed $25 \%$ of the height of the original ostectomy defect. The mean callus : cortex ratio in the femoral defect in animals after implantation of the autogenous cancellous graft (group 
A) was 1.77 ( $\mathrm{SD} \pm 0.33)$; in animals of group $\mathrm{S}$ after transplantation of our mechanically self-supporting resorbable nanocomposite scaffold from HAP and $0.5 \%$ collagen $(1: 1)$ it was $1.08(\mathrm{SD} \pm 0.13)$; and in animals of group $\mathrm{S}+\mathrm{MSCs}$ after transplantation of scaffold from HAP and $0.5 \%$ collagen (1:1) seeded with mesenchymal stem cells, 1.15 ( $\mathrm{SD} \pm 0.18$ ). A significant difference $(p<0.05)$ was found in the callus : cortex ratios between animals of group A (autogenous cancellous bone graft) and group S + MSCs (scaffold seeded with mesenchymal stem cells). No significant difference was found in the size of bone callus between the animals of group $\mathrm{S}$ (transplantation of scaffold alone) and the animals of group $\mathrm{S}+\mathrm{MSCs}$ (scaffold seeded with mesenchymal stem cells).

\section{Discussion}

The necessity to substitute missing bone tissue in extensive bone defects or to enhance bone tissue healing is relatively frequent in orthopaedics. For this purpose, bone grafts are often clinically used (predominantly autogenous cancellous grafts) that have an irreplaceable use in cases of non-healing fractures or delayed bone healing (Canabela 1984; Burwell 1994; Brinker et al. 1998; Mason and Renberg 2001; Griffon 2002; Kesemenli et al. 2002; Blaeser et al. 2003). The process of bone tissue healing includes heamatoma formation, an inflammatory phase, cartilaginous callus formation, a neovascularization phase, mineralization of the osteoblastic callus, and osteoclastic remodelling of the callus into matured lamellar bone (Einhorn 1998). The healing phase process in extensive bone defects may be also speeded up by using scaffolds. One of the most studied materials for this purpose is hydroxyapatite. The purpose of the scaffold is to control the degree of regeneration and the extent of tissue regeneration, or in case of need, to provide suitable environment for stem cells transplanted into given tissue defects (Chu et al. 2000; Gál et al. 2002; Gál et al. 2007; Jančář et al. 2007; Nečas et al. 2008; Plánka et al. 2007; Crha et al. 2009).

The ratio of the bone callus width to the bone width is used to express the bone defect healing (Grigoryan et al. 2003). As it acquires relative values, it can be used to evaluate bone callus formation in animals of various sizes. In the animals with the bone defect filled with autogenous cancellous bone graft (group A), a significantly larger $(p<0.05)$ callus was found compared to the group treated with transplantation of the scaffold alone (group $\mathrm{S}$ ), or to the group treated with transplantation of the scaffold seeded with mesenchymal stem cells (group S + MSCs).

In present study, the varying size of bone callus was formed in three groups of pigs. Smaller callus formation in groups $\mathrm{S}$ and $\mathrm{S}+\mathrm{MSC}$ compared to the larger callus in group A is probably due to its cylindrical shape simulating the missing bone column at the place of the segmental defect, the scaffold maintains stem cells (and by so doing also the callus formation process) in place of the original section of femoral diaphysis before its osteotomy. Unlike the synthetically produced cylinder of biomaterial (scaffold) reminding by its shape of the missing bone section in place of performed ostectomy, the implanted autogenous cancellous bone graft does not have a pre-formed shape and thus may allow the callus and newly formed bone tissue to spread more to the periphery of the original ostectomy defect.

As a possible cause of callus hypertrophy, instability in place of the bone defect is also mentioned (Lieberman et al. 1999). In these cases, however, hypertrophic bone callus is connected with nonunion. Hypertrophic bone callus is a sign of adequate blood supply in place of the bone defect which secures abundant bone callus formation. Considering the fact that for fixation of segmental ostectomy of the femoral diaphysis in miniature pigs of all the groups in our study the same type of fixation was used, namely flexible bridging osteosynthesis using the five-hole $4.5 \mathrm{~mm}$ titanium LCP (Synthes ${ }^{\circledR}$ Switzerland), we may 
exclude eventual varying stability of fixation with regard to the type of implant used as a possible cause of larger callus formation in group A with the implantation of autogenous cancellous bone graft. In case of segmental fractures and fractures with a large loss of bone tissue (comminuted fracture), the bone plate provides sufficient stability in the fracture line for the bone repair to occur (Piermattei and Flo 1997; Koch 2005; Nečas et al. 2007). Fixation by the bone plate prevents excessive movement in the fracture line and allows bone defect healing without formation of a hypertrophic bone callus. Formation of bone tissue may thus be noted in the place of osteotomy before the formation of bone callus in secondary bone healing (Russel et al. 2007). The bone plate appears as a suitable fixation method in segmental bone defects and compared to intramedullar nails, it better prevents micromovement in the fracture line leading to healing by bone callus which may distort the result of healing after local application of osteoinductive materials (Russel et al. 2007).

Based on the results of this study, it may be concluded that the healing of an iatrogenically created segmental defect of femoral diaphysis by callus in miniature pigs differs regarding the ratio of the bone callus width and the bone width after implantation of an autogenous cancellous graft (larger callus) compared to transplantation of a cylindrical scaffold from hydroxyapatite and $0.5 \%$ collagen, or compared to transplantation of this scaffold seeded with MSCs (smaller callus). Unlike a scaffold in the shape of the original bone column, a freely placed autogenous cancellous graft may allow the newly formed tissue to spread more to the periphery of the ostectomy defect.

\section{Hojení segmentálního defektu kosti po implantaci autogenního spongiózního kostního štěpu ve srovnání se skafoldem z hydroxyapatitu a $0,5 \%$ kolagenu v kombinaci s mezenchymovými kmenovými buňkami}

V současné době se soustředí pozornost na hledání možností léčby rozsáhlých defektů kostí cestou miniinvazivní osteosyntézy, implantací biomateriálů a mezenchymových kmenových buněk. Tato studie hodnotí hojení segmentálních defektů femurů miniaturních prasat na základě rentgenologického stanovení poměru kalus:kortex za 16 týdnů po ostektomii. Velikost vzniklého svalku byla statisticky významně větší $(p<0,05)$ u zvířat po implantaci autogenního spongiózního štěpu (skupina $\mathrm{A}$, poměr kalus:kortex $1,77 \pm 0,33$ ) ve srovnání se zvíraty po implantaci cylindrického skafoldu z hydroxyapatitu a 0,5\% kolagenu (skupina $\mathrm{S}$, poměr kalus:kortex $1,08 \pm 0,13$ ) a zviŕaty ze skupiny $\mathrm{S}$ po transplantaci tohoto skafoldu osazeného MSCs (skupina S+MSCs, poměr kalus:kortex 1,15 $\pm 0,18$ ). Nebyl zaznamenán statisticky významný rozdíl ve velikosti svalku u zviŕat ze skupin S a S + MSCs. Volně vložený autogenní spongiózní štěp může, na rozdíl od skafoldu ve tvaru původního sloupce kosti, umožňovat širrení novotvořené tkáně více k periferii ostektomického defektu.

Implantované cylindrické skafoldy (s a bez MSCs) podporují tvorbu svalku př́mo v místě původního sloupce kosti po segmentální ostektomii femuru, a mohou být úspěšně použity v léčbě rozsáhlých kostních defektů.

\section{Acknowledgement}

This work was supported by the Ministry of Education, Youth and Sports of the Czech Republic (Research Project NPV II 2B06130). Preliminary results of the study were presented at the conference "School, Science, Practice II" in 2009 in Košice and published in the proceedings.

\section{References}

Attawia M, Kadiyala S, Fitzgerald K, Kraus K, Bruder SP 2001: Cell-based approaches for bone graft substitutes, in Laurencin CT (ed): Bone Graft Substitutes. West Conshohocken, PA, ASTM International pp. 126-141

Blaeser LL, Gallagher JG, Boudrieau RJ 2003: Treatment of biologically inactive nonunions by a limited en bloc ostectomy and compression plate fixation: A review of 17 cases. Vet Surg 32: 91-100 
Brinker WO, Olmstead ML, Sumner-Smith G, Prieur WD 1998: Manual of internal fixation in small animals. AO Publishing. Springer-Verlag Inc., 286 p.

Bruder SP, Fox BS 1999: Tissue engineering of bone. Cell based strategies. Clin Orthop 367: S68-S83

Burwell RG 1994: History of bone grafting and bone substitutes with special reference to osteogenic induction. In: Urist MR, O’Connor BT, Burwell RG: Bone grafts, derivatives and substitutes. Cambridge, ButterworthHeinemann Ltd.: 1-102

Cabenela ME 1984: Open cancellous bone grafting of infected bone defect. Orthop Clin North Am 15: 427-440

Chu TMG, Hollister SJ, Halloran JW, Feinberg SF, Orton DG 2002: Manufacturing and characterization of 3-D hydroxyapatite bone tissue engineering scaffolds. Ann YN Acad Sci 961: 114-117

Crha M, Nečas A, Srnec R, Janovec J, Stehlík L, Raušer P, Urbanová L, Plánka L, Jančář J, Amler J 2009: Mesenchymal stem cells in bone tissue regeneration and application to bone healing. Acta Vet Brno 78: $635-645$

Einhorn TA 1998. The cell and molecular biology of fracture healing. Clin Orthop Suppl 355: S7-S21

Fitch R, Kerwin S, Newman-Gage H, Sinibaldi KR 1997: Bone autografts and allografts in dogs. Comp Cont Ed Pract Vet 19: 558-578

Gál P, Nečas A, Adler J, Teyschl O, Fabián P, Bibrová S 2002: Transplantation of the autogenous chondrocyte graft to physeal defects: an experimental study in pigs. Acta Vet Brno 71: 327-332

Gál P, Nečas A, Plánka L, Kecová H, Křen L, Krupa P, Hlučilová J, Usvald D 2007: Chondrocytic potential of allogenic mesenchymal stem cells transplanted without immunosuppression to regenerate physeal defect in pigs. Acta Vet Brno 76: 253-263

Griffon DJ 2002: Enhancing bone healing. Proc American College of Veterinary Surgeons Scientific meeting, San Diego, USA: 193-196

Grigoryan M, Lynch JA, Fierlinger AL Guermazi A, Fan B, MacLean DB, MacLean A, Genant HK 2003: Quantitative and qualitative assessment of closed fracture healing using computed tomography and conventional radiography. Acad Radiol 10: 1267-1273

Jaiswal N, Haynesworth SE, Caplan AI, Bruder SP 1997: Osteogenic differentiation of purified, culture-expanded human mesenchymal stem cells in vitro. J Cell Biochem 64: 295-312

Jančář J, Slovíková A, Amler E, Krupa P, Kecová H, Plánka L, Gál P, Nečas A 2007: Mechanical response of porous scaffolds for cartilage engineering. Phys Res 56: S17-S25

Kattapuram VS, Philips WC, Mankin HJ 1989: Intercalary bone allografts: Radiographic evaluation. Radiology 170: $137-141$

Kesemenli CC, Subasi M, Arslan H, Necmioglu S, Kapukaya A 2002: Treatment of humeral diaphyseal nonunions by interlocked nailing and autologous bone grafting. Acta Orthop Belg 68: 471-475

Koch D 2005: Screws and plates. In: AO Principles of fracture management in the dog and cat. AO Publishing, Switzerland, pp. 26-50

Kraus KH, Kirker-Head C 2006: Mesenchymal stem cells and bone regeneration. Vet Surg 35: 232-242

Kresten CHR, Noske H, Vasilevska V, Weber M, Schueller G, Imhof H, Czerny CH 2006: MDCT Versus digital radiography in the evaluation of bone healing in orthopedic patients. AJR 186: 1754-1760

Krettek C, Foreword L 1997: Concepts of minimally invasive plate osteosynthesis. Injury 28 Suppl. 1: A1-2

Lieberman JR, Daluiski A, Stevenson S, Wu L, McAllister P, Lee YP, Kabo JM, Finerman GA, Berk AJ, Witte ON 1999: The effect of regional gene therapy with bone morphogenetic protein -2 producing bone-marrow cells on the repair of segmental femoral defects in rats. 81: 905-917

Marsh DR, Li G 1999: The biology of fracture healing: optimising outcome. Br Med Bull 55: 856-869

Mason DR, Renberg WC 2001: Postsurgical enhancement of fracture repair: biological alternatives to bone grafting. Comp Cont Ed Pract Vet 23: 272-279

Muschler GF, Midura RJ 2002: Connective tissue progenitors: practical concepts for clinical applications. Clin Orthop 395: 66-80

Nečas A, Plánka L, Srnec R, Raušer P, Urbanová L, Lorenzová J, Crha M, Jančář J, Gál P 2008: Use of biomaterials and stem cells in the treatment of articular cartilage, meniscal, physeal, bone, ligamentous and tendineous defects. Acta Vet Brno 77: 277-284

Nečas A, Proks P, Srnec R, Stehlík L, Urbanová L, Crha M, Raušer P, Janovec J, Dvořák M 2009: Současné trendy v chirurgické léčbě segmentálních fraktur (MIPO, LCP, biomateriály). (In Czech, Contemporary trends in surgical treatment of segmental fractures (MIPO, LCP, biomaterials)). In Zborník príspevkov z odbornej konferencie „Škola, veda, prax II.“, Košice, Slovenská republika: UVL Košice, pp. 123-127

Nečas A, Srnec R, Raušer P, Crha M, Urbanová L, Lorenzová J, Kecová H, Lexmaulová L, Fichtel T, Dvořák M 2008: Experimentální využití skafoldů osazených mezenchymovými buňkami v léčbě defektů tkání muskulokeletálního systému. (In Czech, Experimental application of scaffolds seeded with mesenchymal cells in treatment of the musculoskeletal system defects.) Veterinářství 58: 685-691

Nečas A, Urbanová L, Srnec R 2007: Principy použití LCP plotének. (Principles of using LCPs.) In: Nečas A, Beale BS, Hulse DA, Srnec R et al.: Osteotomie a nové trendy v léčbě nemocí kostí a kloubů. VFU Brno: $19-22$

Piermattei DL, Flo GL 1997: Brinker, Piermattei, and Flo's Handbook of Small Animal Orthopedics and Fracture Repair. $3^{\text {rd }}$ ed. Philadelphia: WB Saunders, pp. 24-146 
Pittenger MF, Mackay AM, Beck SC, Jaiswal K, Douglas R, Mosca JD, Moorman MA, Simonetti DW, Craig S, Marshak DR 1999: Multilineage potential of adult human mesenchymal stem cells. Science 284: 143-147

Plánka L, Nečas A, Gál P, Kecová H, Filová E, Křen L, Krupa P 2007: Prevention of bone bridge formation using transplantation of the autogenous mesenchymal stem cells to physeal defects: An experimental study in pigs. Acta Vet Brno 76: 257-266

Russell G, Tucci M, Conflitti J, Graves M, Wingerter S, Woodall J, Ragab A 2007: Characterization of femoral segmental nonunion model in laboratory rats: Report of a novel surgical technique. J Invest Surg 20: 249-255

Yoo JU, Johnstone B 1998: The role of osteochondral progenitor cells in fracture repair. Clin Orthop 355: S73-S81 
Plate VII

Nečas A. et al.: Healing of Large ... pp. 607-612

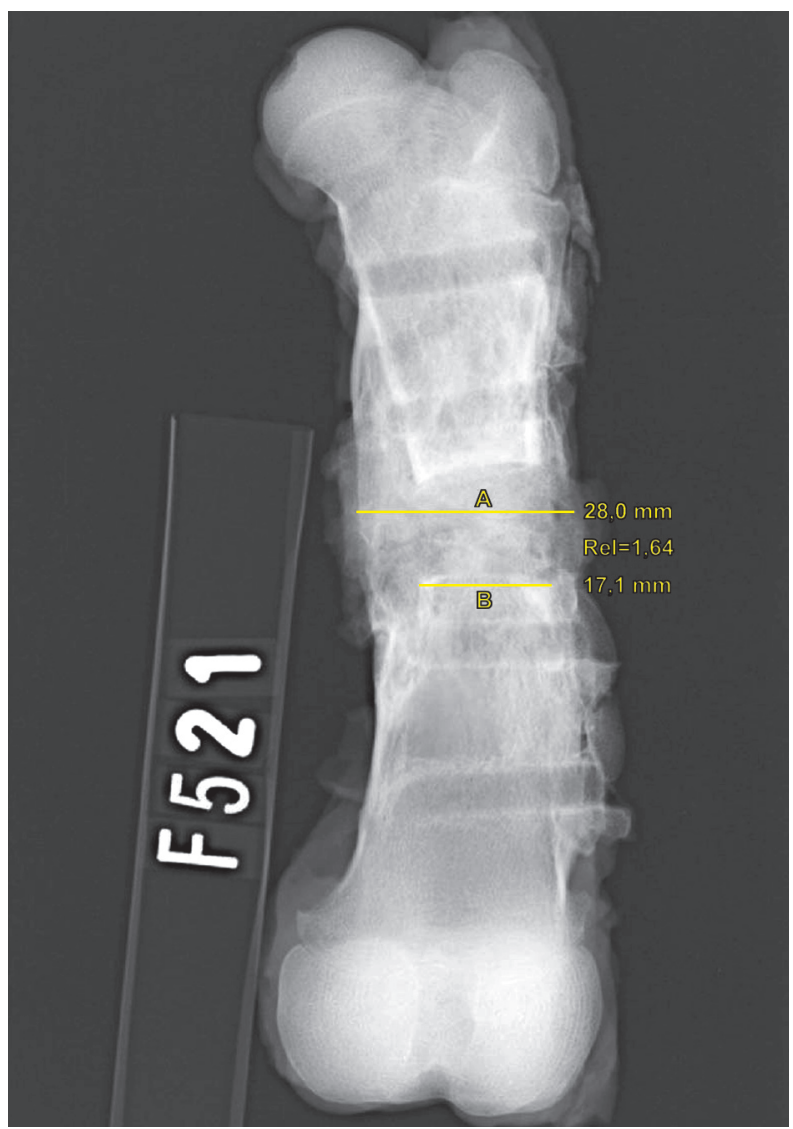

Fig. 1. Measurement of the bone callus width (line A) and the bone width (line B) in a $\mathrm{CrCd}$ view of the femur of the miniature pig. 